\title{
UJI BEBERAPA KONSENTRASI EKSTRAK UMBI GADUNG (Dioscorea hispida Dennst) TERHADAP HAMA KEONG MAS (Pomacea canaliculata L.)
}

\section{Test Several Concentration of Gadung Tuber Extract (Dioscorea hispida Dennst) to Golden Snail Pest (Pomacea canaliculata L.)}

\author{
Alfaizal, Hafiz Fauzana dan Desita Salbiah \\ Program Studi Agroteknologi, Fakultas Pertanian, Universitas Riau \\ Kampus Bina Widya km 12.5, Pekanbaru \\ Email: Faizalnanceno29@gmail.com/082381975451 \\ [Diterima: Februari 2021; Disetujui: April 2021]
}

\begin{abstract}
Riau is one of a lowland rice producing provinces. One of the pests that can reduce rice productivity is the golden snail (Pomacea canaliculata L.). The solution for controlling the golden snail ( $P$. canaliculata L.). Pest uses environmentally friendly control techniques, namely botanical pesticides of gadung tubers. This study aims to obtain a concentration of the extract of gadung tuber flour (Dioscorea hispida Dennst) which is effective in controlled the attack of golden snails $(P$. canaliculata L.) in lowland rice plants. This research was conducted experimentally using completely randomized design (CRD) consisting of five treatments and four replications, in order to obtain 20 experimental units. The treatments consisted of concentrations of gadung tubers extract, namely $0 \mathrm{~g} . \mathrm{l}^{-}$ 1, 25 g. $l^{-1}, 50$ g. $l^{-1}, 75$ g. $l^{-1}$, and 100 g. $l^{-1}$. Observations included the initial dst time to snail death, lethal time 50 (LT 50), daily total mortality, and behavior changes in behavior. The results showed that the application of 100 g.l concentration of gadung tuber extract treatment caused the highest total mortality of golden snails ( $P$. canaliculata L.) of $74.99 \%$, but it was not effective yet in controlling the golden snail pest because it was not able to kill the golden snail above $80 \%$.
\end{abstract}

Keywords: Rice Plant, Pomacea canaliculata L ., Botanical Pesticide, Dioscorea hispida Dennst.

\begin{abstract}
ABSTRAK
Riau merupakan salah satu provinsi penghasil padi sawah. Hama yang dapat menurunkan produktivitas padi sawah salah satunya adalah keong mas (Pomacea canaliculata L.). Solusi penanggulangan hama Keong mas (Pomacea canaliculata L.) menggunakan teknik pengendalian yang ramah lingkungan yaitu pestisida nabati umbi gadung. Penelitian ini bertujuan untuk mendapatkan konsentrasi ekstrak tepung umbi gadung (Dioscorea hispida Dennst) yang efektif dalam mengendalikan serangan keong mas (Pomacea canaliculata L.) pada tanaman padi sawah. Penelitian ini dilaksanakan secara eksperiman dengan menggunakan rancangan acak lengkap (RAL) yang terdiri dari lima perlakuan dan empat ulangan, sehingga diperoleh 20 unit percobaan. Perlakuan terdiri dari konsentrasi ekstrak umbi gadung yaitu 0 g. $l^{-1}, 25$ g. $l^{-1}, 50$ g. $l^{-1}, 75$ g. $l^{-1}$ dan 100 g. $l^{-1}$. Pengamatan meliputi waktu awal kematian keong mas, lethal time 50 (LT50), mortalitas harian, mortalitas total, perubahan perilaku. Hasil penelitian menunjukkan bahwa aplikasi perlakuan ekstrak umbi gadung konsentrasi $100 \mathrm{~g} .^{-1}$ menyebabkan mortalitas total tertinggi hama keong mas (P. canaliculata) sebesar $74,99 \%$, namun belum efektif mengendalikan hama keong mas karena belum mampu mematikan keong mas diatas $80 \%$.
\end{abstract}

Kata kunci: Tanaman Padi, Keong Mas (Pomacea canaliculata L.), Pestisida Nabati, Ekstrak Umbi Gadung (Dioscorea hispida Dennst).

\section{PENDAHULUAN}

Tanaman padi (Oryza sativa) merupakan salah satu komoditas pangan yang harus terpenuhi kecukupannya untuk menunjang kelangsungan hidup sebagian besar penduduk, khususnya di Indonesia. Hama penting yang dapat menurunkan produktivitas tanaman padi sawah adalah Keong mas (Pomacea canaliculata L.) yang merupakan salah satu 
hama yang dapat menyebabkan kerugian pada usaha tani padi apabila tidak dikendalikan. Menurut Wiratno et al. (2011) bahwa keong mas merupakan salah satu hama penting pada tanaman padi yang memiliki daya rusak yang sangat tinggi dengan masa reproduksi 2-36 bulan dan kemampuan bertelur 1.000-1.200 butir/bulan, dengan daya rusak mencapai 84,17\% (Wijayanti et al, 2016).

Teknik pengendalian hama keong mas dapat dilakukan dengan beragam cara seperti fisik, mekanik maupun kimia. Selama ini pengendalian hama keong mas di tingkat petani dilakukan secara kimia menggunakan pestisida sintetis namun cara ini masih belum efektif (Yasa et al., 2013). Penggunaan moluskisida sintetis dapat menyebabkan efek samping, seperti resistensi hama, perubahan sifat fisik kimia tanah, dan pencemaran lingkungan. Oleh karena itu, perlu ditemukan teknologi yang bisa menekan pengembangan hama ramah lingkungan seperti penggunaan pestisida nabati (Kardinan, 2011).

Pestisida nabati adalah produk alam berasal dari tanaman yang mengandung kelompok metabolit sekunder yang mengandung banyak senyawa bioaktif seperti alkaloid, terpenoid, fenolik, dan zat-zat kimia sekunder lainnya. Salah satu pestisida nabati yang dapat digunakan yaitu pestisida nabati yang terbuat dari umbi gadung. Gadung (Discorea hispida Dennst) merupakan anggota umbi-umbian yang mengandung zat gizi dan senyawa racun berbahaya. Umbi gadung mengandung alkaloid dioskorin dan seringkali bersifat toksik (Kardinan, 2011).

Hasil penelitian Thamrin dan Asikin (2003) bahwa bahan nabati yang terbuat dari ekstrak umbi gadung dapat mematikan $90 \%$ larva hama Plutella sp dengan konsentrasi 50 ml..$^{-1}$ air . Menurut Sukayat (2010) penggunaan ekstrak umbi gadung dengan konsentrasi 5-10 ml. $1^{-1}$ air dapat mematikan belalang dalam waktu 1-2 jam dan untuk hama ulat dapat mati dalam jangka 5-6 jam. Dadang dan Prijono (2008) menyatakan bahwa pestisida nabati dikatakan efektif apabila $10 \%$ pelarut air maksimal konsentrasi 90 g. $1^{-1}$ air dapat mengakibatkan kematian hama uji $\geq 80 \%$.

Penelitian bertujuan untuk mendapatkan konsentrasi ekstrak tepung umbi gadung (Dioscorea hispida Dennst) yang efektif dalam mengendalikan serangan keong mas (Pomacea canaliculata $\mathrm{L}$ ) pada tanaman padi sawah.

\section{METODOLOGI PENELITIAN}

Penelitian telah dilaksanakan di lahan Kebun Percobaan Fakultas Pertanian Universitas Riau, Pekanbaru. Penelitian dilaksanakan selama tiga bulan dari bulan November sampai Januari 2019.

Penelitian dilaksanakan secara eksperimen menggunakan rancangan acak lengkap (RAL) yang terdiri dari 5 perlakuan dan diulang 4 kali sehingga diperoleh 20 unit percobaan. Perlakuan yang diberikan pada masing-masing unit percobaan adalah konsentrasi ekstrak umbi gadung 0 g. $1^{-1}$ air, 25 g. $l^{-1}$ air, 50 g. $1^{-1}$ air, 75 g. $l^{-1}$ air, dan 100 g. $l^{-1}$ air. Penelitian dimulai dari penyemaian dan penanaman benih padi, penyediaan dan infestasi keong mas uji, penyediaan dan pembuatan ekstrak umbi gadung, dan aplikasi perlakuan ekstrak umbi gadung pada keong mas uji. Parameter yang diamati yaitu waktu awal kematian (jam), lethal time 50 (jam), mortalitas harian (\%), mortalitas total (\%), dan perubahan perilaku dan morfologi. Pengamatan mortalitas harian, perubahan tingkah laku dan morfologi disajikan secara deskripsi dalam bentuk gambar, sedangkan waktu awal kematian (jam), lethal time 50 (jam) dan mortalitas total (\%), dianalisis secara statistik menggunakan analisis sidik ragam. Hasil sidik ragam yang berbeda nyata dilakukan uji lanjut menggunakan BNJ pada taraf $5 \%$.

\section{HASIL DAN PEMBAHASAN}

Penelitian Uji Beberapa Konsentrasi Ekstrak Umbi Gadung (Dioscorea hispida Dennst) terhadap Hama Keong Mas (Pomacea canaliculata L) pada Padi Sawah (Oryza sativa L.) telah dilaksanakan di Kebun Percobaan Fakultas Pertanian Universitas Riau pada suhu rata-rata $29,39{ }^{\circ} \mathrm{C}$ dan rata-rata kelembaban $76,71 \%$

\section{Waktu Awal Kematian (jam)}

Hasil sidik ragam menunjukkan bahwa pemberian beberapa konsentrasi ekstrak umbi gadung memberikan pengaruh yang nyata terhadap waktu awal kematian keong mas. Hasil waktu awal kematian keong mas setelah dilakukan uji BNJ pada taraf 5\% dapat dilihat pada Tabel 1. 
Tabel 1. Waktu Awal Kematian Hama Keong Mas Setelah Pemberian Beberapa Konsentrasi Ekstrak Umbi Gadung.

\begin{tabular}{cc}
\hline $\begin{array}{c}\text { Konsentrasi ekstrak } \\
\text { umbi gadung } \\
\left(\mathrm{gl}^{-1}\right)\end{array}$ & $\begin{array}{c}\text { Waktu awal kematian } \\
(\text { jam })\end{array}$ \\
0 & $168,00 \mathrm{c}$ \\
25 & $9,75 \mathrm{~b}$ \\
50 & $7,25 \mathrm{ab}$ \\
75 & $5,25 \mathrm{a}$ \\
100 & $4,50 \mathrm{a}$ \\
\hline Keterangan: & Angka-angka yang diikuti oleh huruf kecil \\
yang berbeda memberikan perbedaan yang & nyata menurutuji lanjut BNJ pada taraf $5 \%$. \\
& Setelah ditransformasi dengan formula $\sqrt{\mathrm{y} .}$
\end{tabular}

Tabel 1 menunjukkan bahwa pemberian konsentrasi ekstrak umbi gadung dapat mempercepat waktu awal kematian keong mas. Pemberian konsentrasi ekstrak umbi gadung 100 g. $^{-1}$ menyebabkan waktu awal kematian cenderung tercepat yaitu 4,50 jam setelah aplikasi berbeda tidak nyata dengan konsentrasi 50 g. $1^{-1}$ dan 75 g..$^{-1}$ yaitu 7,25 dan 5,25 jam setelah aplikasi. Hal ini diduga karena ekstrak umbi gadung konsentrasi 50 g.l ${ }^{-}$ , 75 g. $^{-1}, 100$ g. $1^{-1}$ mengandung senyawa glikosida sianogenik yang tinggi serta dapat membentuk racun asam sianida $(\mathrm{HCN})$ yang dapat menyerang sistem pernapasan hingga ke sistem saraf serangga menyebabkan serangga mengalami kematian secara perlahan-lahan. Hal ini sesuai dengan pendapat Kardinan (2011) yang mengatakan bahwa umbi gadung mengandung racun asam sianida $(\mathrm{HCN})$ yang dapat menyebabkan kelumpuhan pada sistem pencernaan hingga sistem syaraf .

Pemberian konsentrasi ekstrak umbi gadung $100 \mathrm{~g} . \mathrm{l}^{-1}$ berbeda nyata dengan konsentrasi 25 g. $l^{-1}$. Hal ini diduga dengan pemberian konsentrasi ekstrak umbi gadung $100 \mathrm{~g} . \mathrm{l}^{-1}$ memiliki toksisitas yang lebih tinggi dibandingkan dengan konsentrasi tersebut, Peningkatan konsentrasi yang diberikan dapat meningkatkan jumlah bahan aktif sehingga akumulasi bahan aktif menjadi banyak. Sari (2013) melaporkan bahwa peningkatan konsentrasi berbanding lurus dengan peningkatan bahan racun yang terakumulasi pada tubuh serangga, sehingga daya bunuh semakin cepat. Hasil penelitian Ferinda (2017) juga menunjukkan konsentrasi tertinggi awal kematian keong mas menjadi lebih cepat.
Umbi gadung mengandung senyawa glukosida sianogenik yang jika terurai menghasilkan senyawa HCN (asam sianida) yang dapat mengganggu sistem pencernaan dan sistem syaraf. Svasty (1999) menyatakan bahwa senyawa asam sianida merupakan senyawa yang berbahaya bagi organisme yang mengkonsumsinya. Senyawa HCN mengganggu sistem pencernaan hingga syaraf sehingga mengakibatkan kematian terjadi lebih cepat. Menurut Sulfahri (2006) asam sianida merupakan salah satu senyawa yang dapat masuk sebagai racun kontak pada tubuh serangga melalui lubang alami. Setelah masuk ke dalam tubuh, kemudian menyebar ke pusat saraf sehingga akan berpotensi memberikan tekanan serta menurunkan metabolisme organ dalam dan menghambat aktivitas metabolisme sehingga mengalami kematian yang lebih cepat.

Insektisida nabati umbi gadung masuk ke dalam tubuh hama keong mas sebagai racun kontak. Pemberian konsentrasi ekstrak umbi gadung pada hama keong mas dilakukan dengan cara menyemprotkan secara langsung ke bagian tubuh keong mas tetapi daya racun yang terdapat pada umbi gadung relatif lambat dalam proses toksisitasnya. Hal ini dikarenakan adanya cangkang yang menutupi tubuh keong mas tersebut. Hal ini didukung oleh pendapat Gassa et al. (2007) bahwa daya racun pestisida untuk racun kontak terhadap spesies berbeda-beda, karena adanya perbedaan kontaminasi seperti adanya rambut, lapisan lilin, maupun ciri morfologi lainnya.

Gejala awal kematian $P$. canaliculata $\mathrm{L}$ ditandai oleh perubahan tingkah laku dan perubahan morfologi. Gejala akut ditimbulkan akibat terpapar ekstrak umbi gadung yaitu aktivitas menurun, dehidrasi berlebihan dan merusak sistem pencernaan. Senyawa sianida merusak sistem pencernaan serta saraf keong mas. Sistem saraf pada keong mas akan mengalami gangguan yang akan berpengaruh terhadap aktivitas metabolisme sehingga keong mas mengalami dehidrasi berlebihan. Hal ini dibuktikan dengan kondisi keong mas yang berlendir lebih banyak dan tubuhnya keluar dari cangkang. Gejala perubahan keong mas yang ditimbulkan akibat terpapar insektisida nabati umbi gadung dapat dilihat pada Gambar1. 

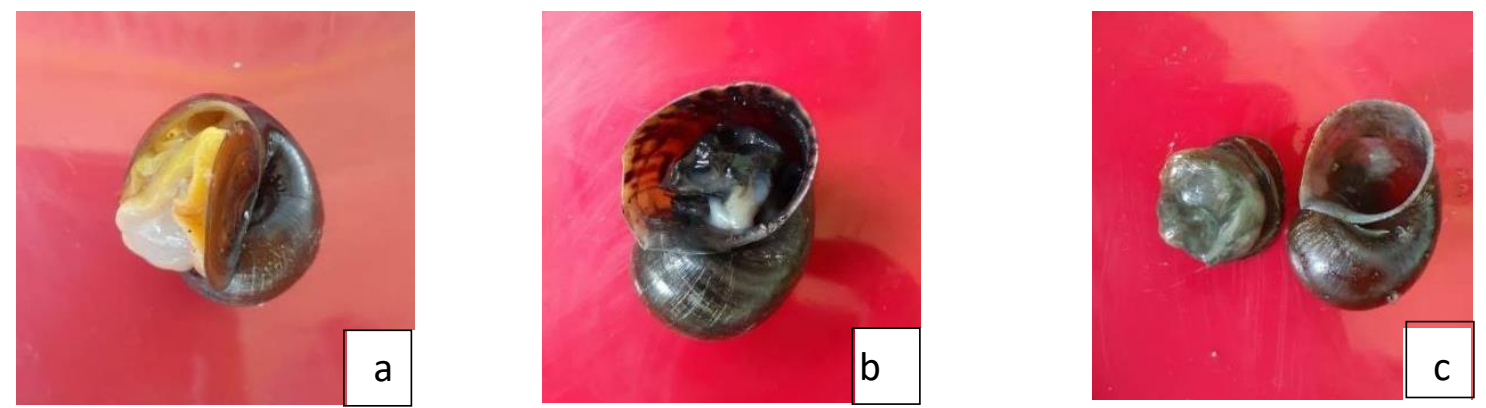

Gambar 1. Perubahan Morfologi Hama Keong Mas, (a) Keong Mas Sebelum Aplikasi Umbi Gadung (b) Keong Mas yang Mati Setelah Aplikasi Umbi Gadung (c) Tubuh Keong Mas yang Lepas dari Cangkangnya.

\section{Lethal Time $50\left(\mathrm{LT}_{50}\right)(\mathrm{jam})$}

Hasil sidik ragam menunjukkan bahwa pemberian beberapa konsentrasi ekstrak umbi gadung memberikan pengaruh yang nyata terhadap lethal time (LT50) hama keong mas. Hasil rata-rata lethal time (LT50) hama keong mas setelah dilakukan uji BNJ pada taraf 5\% dapat dilihat pada Tabel 2.

Tabel 2. Lethal Time (LT50) Setelah Pemberian Beberapa Konsentrasi Ekstrak Umbi Gadung (D. hispida).

\begin{tabular}{cc}
\hline $\begin{array}{c}\text { Konsentrasi ekstrak umbi } \\
\text { gadung } \\
\left(\mathrm{gl}^{-1}\right)\end{array}$ & $\begin{array}{c}\text { Lethal time (LT50) } \\
\text { (jam) }\end{array}$ \\
0 & $168,00 \mathrm{c}$ \\
25 & $33,00 \mathrm{~b}$ \\
50 & $22,75 \mathrm{ab}$ \\
75 & $18,50 \mathrm{ab}$ \\
100 & $11,00 \mathrm{a}$ \\
\hline Keterangan: & Angka-angka pada lajur yang diikuti oleh \\
huruf kecil yang tidak sama berbeda nyata & menurut uji BNJ pada taraf $5 \%$ setelah \\
ditransformasikan ke dalam $\sqrt{ } y$.
\end{tabular}

Tabel 2 menunjukkan bahwa pemberian konsentrasi ekstrak umbi gadung berbeda nyata terhadap kematian 50\% keong mas, yang terjadi pada kisaran 11-33 jam. Pemberian konsentrasi ekstrak umbi gadung $100{\mathrm{~g} . \mathrm{l}^{-1}}^{-1}$ menyebabkan lethal time (LT50) hama keong mas yaitu 11 jam setelah aplikasi berbeda tidak nyata dengan pemberian konsentrasi ekstrak umbi gadung 50 g. $1^{-1}$ dan 75 g..$^{-1}$ yaitu 22,75 jam dan 18,50 jam setelah aplikasi namun berbeda nyata dengan pemberian konsentrasi ekstrak umbi gadung 25 g..$^{-1}$ dan Pemberian konsentrasi ekstrak umbi gadung 0 g. $1^{-1}$.

Pemberian konsentrasi ekstrak umbi gadung 25 g. $\mathrm{l}^{-1}$ menyebabkan kematian $50 \%$ keong mas dalam waktu 33 jam setelah aplikasi, berbeda tidak nyata dengan konsentrasi 50 g..$^{-1}$ dan 75 g..$^{-1}$ namun berbeda nyata dengan pemberian konsentrasi ekstrak umbi gadung 100 g. $l^{-1}$ dan pemberian konsentrasi ekstrak umbi gadung 0 g. $1^{-1}$. Hal ini diduga karena pemberian konsentrasi umbi gadung 25 g. $1^{-1}, 0$ g. $1^{-1}, 75$ g. $1^{-1}$ belum optimal dalam menyebabkan kematian 50\% keong mas, sehingga butuh waktu yang lebih lama dalam mematikan serangga uji. Hal ini sesuai dengan pendapat Tukimin dan Rizal (2002) yang menyatakan bahwa pestisida nabati pada umumnya akan bekerja secara maksimal dalam 24 jam setelah aplikasi. Pemberian konsentrasi ekstrak umbi gadung 25 g. $1^{-1}$ memiliki konsentrasi yang lebih sedikit dan bahan aktif yang terkandung didalamnya juga relatif lebih rendah sehingga kemampuannya dalam mematikan 50\% hama keong mas relatif lama. Menurut Natawigena (1993) bahwa proses kematian hama akan semakin cepat dengan penambahan konsentrasi yang digunakan.

Lethal Time (LT50) hama keong mas tanpa pemberian konsentrasi ekstrak umbi gadung berbeda nyata dengan pemberian konsentrasi ekstrak umbi gadung konsentrasi lainnya. Hal ini disebabkan karena pada perlakuan tersebut tidak terdapat konsentrasi ekstrak umbi gadung yang mempunyai daya toksik bagi hama keong mas. Hal ini juga dapat dihubungkan pada tabel 1, dimana waktu awal kematian yang tinggi yaitu 168 jam sehingga kematian 50\% keong mas juga lebih lama.

\section{Mortalitas Harian (\%)}

Hasil pengamatan mortalitas harian hama keong mas setelah pemberian beberapa konsentrasi ekstrak umbi gadung menunjukkan bahwa persentase kematian yang terjadi pada hama keong mas mengalami fluktuasi dari hari pertama hingga hari keempat pengamatan. Fluktuasi mortalitas harian hama keong mas 
dapat dilihat pada Gambar 2.



Gambar 2. Fluktuasi Mortalitas Harian Hama Keong Mas Setelah Pemberian Beberapa Konsentrasi Ekstrak Umbi Gadung.

Pengamatan hari pertama menunjukkan persentase kematian tertinggi adalah pemberian konsentrasi 100 g. $1^{-1}$ dengan persentasi kematian yaitu $20,83 \%$. Hal ini karena bahan aktif yang terkandung di dalam ekstrak umbi gadung langsung bereaksi terhadap hama keong mas sehingga mengalami mortalitas harian tertinggi. Pemberian konsentrasi 75 g. $l^{-1}$ menyebabkan mortalitas harian sebesar $12,5 \%$, lebih rendah dari konsentrasi 50 g. $1^{-1}$ yang mengalami mortalitas harian dengan persentase $16,66 \%$, hal ini diduga karena penguapan ekstrak umbi gadung yang terjadi lebih cepat sehingga bahan aktif yang terkadung sedikit dan daya mematikan terhadap hama menjadi lebih rendah. Dadang dan Prijono (2008) menyatakan bahwa beberapa kekurangan insektisida nabati antara lain persistensi insektisida nabati rendah, sehingga bahan aktif yang terkandung cepat menguap. sedangkan konsentrasi $25 \mathrm{~g}^{-1^{-1}}$ memiliki persentasi mortalitas harian terendah yaitu $4,16 \%$. Hal ini dikarenakan senyawa sianida dan saponin belum bereaksi terhadap hama keong mas.

Puncak mortalitas harian pada semua konsentrasi ekstrak umbi gadung terjadi pada hari kedua setelah aplikasi. Pemberian konsentrasi $100{\mathrm{~g} . l^{-1}}^{-1}$ tetap memiliki persentase kematian yang tinggi yaitu $45,83 \%$, konsentrasi 75 g. $1^{-1}$ menyebabkan mortalitas harian yaitu $37,5 \%$, sedangkan konsentrasi 50 g. $1^{-1}$ menyebabkan mortalitas harian sebesar $33,33 \%$ dan konsentrasi 25 g. $1^{-1}$ memiliki persentase mortalitas harian terendah yaitu
$29,16 \%$ sedangkan tanpa pemberian konsentrasi ekstrak umbi gadung tidak menunjukkan kematian pada hama keong mas.

Pengamatan hari ketiga menunjukkan hasil bahwa pemberian konsentrasi 100 g. $\mathrm{l}^{-1}$ mortalitas harian yaitu $8,33 \%$. Hal ini diduga karena jumlah keong mas pada konsentrasi 100 g. $l^{-1}$ banyak yang mati pada pengamatan hari pertama dan kedua. Pemberian konsentrasi 75 g. $l^{-1}$ mortalitas harian yaitu $16,66 \%$ sedangkan konsentrasi 50 g. $1^{-1}$ dan 25 g. $1^{-1}$ mortalitas harian yaitu $12,5 \%$. Persentase mortalitas harian hama keong mas pada semua konsentrasi mengalami penurunan. Hal ini diduga karena daya toksik ekstrak umbi gadung mulai berkurang dan jumlah keong mas juga semakin berkurang jumlahnya.

Pengamatan hari keempat hingga akhir tidak menunjukkan adanya mortalitas harian hama keong mas pada semua konsentrasi, hal ini diduga karena senyawa racun yang terdapat pada ekstrak umbi gadung mulai terdegradasi. Proses degradasi pada kandungan ekstrak umbi gadung menyebabkan toksisitas dan daya bunuhnya menjadi berkurang, sehingga reaksinya menjadi berkurang terhadap hama keong mas. Dadang dan Prijono (2008) menyebutkan bahwa beberapa kekurangan insektisida nabati antara lain persistensi insektisida nabati rendah, sehingga bahan aktif yang terdapat pada insektisida nabati cepat terurai, bahkan terjadi penurunan efikasi yang cepat dari insektisida nabati sehingga memerlukan aplikasi lebih sering atau berulang. Alfrinda et al. (2015) juga menyatakan bahwa bahan-bahan nabati cepat terurai dan residunya mudah hilang, hal ini disebabkan karena senyawa kimia yang ada di dalam bahan nabati mudah terdegradasi oleh lingkungan.

\section{Mortalitas Total (\%)}

Hasil pengamatan mortalitas total $P$. canaliculata setelah dianalisis secara sidik ragam menunjukkan bahwa perlakuan konsentrasi ekstrak umbi gadung memberikan pengaruh yang nyata terhadap mortalitas total $P$. canaliculata dan hasil uji lanjut BNJ pada taraf 5\% dapat dilihat pada Tabel 3.

Tabel 3 menunjukkan bahwa persentase mortalitas total keong mas pada konsentrasi umbi gadung $100{\mathrm{~g} .1^{-1}}^{-}$yaitu $74,99 \%$ berbeda tidak nyata dengan konsentrasi 50 g. $1^{-1}$ dan 75 g. $1^{-1}$, yaitu masing masing $66,60 \%$ dan 62,49 
$\%$, berbeda nyata dengan pemberian konsentrasi ekstrak umbi gadung 25 g. $1^{-1}$ dan pemberian 0 g. $1^{-1}$ konsentrasi ekstrak umbi gadung. Hal ini diduga karena semakin tinggi konsetrasi yang digunakan semakin tinggi kandungan zat racun yang ada sehingga semakin tinggi daya bunuh terhadap hama. Hal ini sesuai pendapat Purba (2007) yang juga menyatakan bahwa peningkatan konsentrasi berbanding lurus dengan peningkatan bahan racun tersebut, sehingga kemampuan tingkat mortalitas serangga sangat ditentukan oleh tinggi rendahnya konsentrasi pestisida nabati yang digunaakan. Menurut Basmiyanti (1995) sifat toksisitas suatu bahan tergolong toksik jika mampu membunuh hingga $50 \%$ atau lebih dari populasi hama uji.

Tabel 3. Mortalitas Total $P$. canaliculata Total Setelah Pemberian Beberapa Konsentrasi Ekstrak Umbi Gadung.

\begin{tabular}{cc}
\hline $\begin{array}{c}\text { Konsentrasi ekstrak } \\
\text { umbi gadung g. }{ }^{-1}\end{array}$ & Mortalitas total $(\%)$ \\
\hline 0 & $0,00 \mathrm{a}$ \\
25 & $45,83 \mathrm{~b}$ \\
50 & $62,49 \mathrm{bc}$ \\
75 & $66,60 \mathrm{c}$ \\
100 & $74,99 \mathrm{c}$ \\
\hline
\end{tabular}

Angka-angka pada lajur yang diikuti oleh huruf kecil yang tidak sama berbeda nyata menurut uji BNJ pada taraf 5\% setelah ditransformasikan arcsin $\mathrm{x}$.

Menurut Setiawan dan Ahmad (2014), kandungan yang ada pada umbi gadung yaitu senyawa glukosida sianogenik yang jika terurai menghasilkan senyawa HCN (asam sianida). Proses masuknya racun ke dalam tubuh keong mas sebagai racun kontak. Racun kontak masuk sebagai racun saraf sehingga dapat mengganggu aktifitas dan mempengaruhi metabolisme dalam tubuh dengan cepat yang dapat menyebabkan kematian. terserap oleh dinding-dinding alat pencernaan tersebut, kemudian menyebar hingga ke pusat saraf sehingga akan berpotensi memberikan tekanan serta menurunkan metabolisme organ dalam dan menghambat aktivitas keong mas sehingga mengalami kematian (Afifah, 2015). Djaafar et al. (2009) menyatakan bahwa kedua senyawa tersebut memiliki toksisitas tinggi yang dapat mengganggu sistem saraf bagi organisme yang mengkonsumsinya.

Hasil penelitian yang dilakukan menunjukkan perubahan gejala awal kematian pada hama keong mas yaitu terdapat cairan seperti lendir berwarna hijau pada bagian dari tubuh keong mas tersebut dan diikuti dengan berkurangnya daya makan dari keong mas yang diakibatkan senyawa racun perut yang merusak sistem pencernaan dari keong mas tersebut. Sesuai dengan pernyataan Tarumingkeng (2001) bahwa penghambat metabolisme menyebabkan serangga mengalami kelumpuhan alat pernapasan dan mengakibatkan disfungsional pada bagian pencernaan, sehingga terjadi gejala inaktif (tidak mampu makan) serta paralisis (kelumpuhan) kemudian mati. Gejala kematian dari keong mas tersebut diikuti dengan adanya aroma bau busuk yang menyengat.

Perlakuan ekstrak tepung daun sirih hutan dengan konsentrasi tertinggi yaitu 100 g. $1^{-1}$ air mampu mematikan hama keong mas P. canaliculata sebesar $74,99 \%$, lebih cepat jika dibandingkan dengan pemberian konsentrasi ekstrak umbi gadung 25 g. $.^{-1}, 50$ g. $.^{-1}, 75$ g..$^{-1}$ dan pemberian 0 g..$^{-1}$ konsentrasi ekstrak umbi gadung, namun belum efektif bila digunakan sebagai pestisida nabati. Pendapat ini disesuaikan dengan Dadang dan Prijono (2008) yang menyatakan bahwa pestisida nabati dikatakan efektif apabila perlakuan tersebut dapat mengakibatkan kematian hama uji melebihi $80 \%$.

\section{KESIMPULAN DAN SARAN}

\section{Kesimpulan}

Hasil penelitian dapat disimpulkan bahwa aplikasi perlakuan ekstrak umbi gadung konsentrasi 100 g. $^{-1}$ menyebabkan mortalitas total keong mas $(P$. canaliculata) cenderung tertinggi yaitu sebesar $74,99 \%$, namun belum efektif mengendalikan hama keong mas karena belum mampu mematikan keong mas $\geq 80 \%$.

\section{Saran}

Dari hasil penelitian disarankan penelitian lanjutan menggunakan ekstrak umbi gadung menggunakan pelarut organik, agar didapatkan konsentrasi efektif dengan mortalitas besar dari $80 \%$.

\section{DAFTAR PUSTAKA}

Alfindra, R. R. dan J. H. Laoh. 2015. Pengaruh Lama Penyimpanan Tepung Daun Sirih Hutan (Piper aduncum L.) dalam Mengendalikan Hama Kutu Daun Persik (Myzus persicae Sulzer) (Homoptera: Aphididae) pada Tanaman Cabai (Capsicum annum 
Uji Beberapa Konsentrasi Ekstrak Umbi Gadung (Dioscorea hispida Dennst) terhadap Hama Keong Mas (Pomacea canaliculata L.)

L.). Jurnal Online Mahasiswa Universitas Riau, 2(1): 1-9.

Basmiyanti. 1995. Uji Daya Basmi Ekstrak Akar Tuba (Derris eliptica) terhadap Kehidupan Larva Nyamuk Culex sp. Skripsi (Tidak Dipublikasikan). Universitas Hasanuddin, Makassar.

Dadang dan D. Prijono. 2008. Insektisida Nabati Prinsip, Pemanfaatan dan Pengembangan. Departemen Proteksi Tanaman Institute Pertanian Bogor. Bogor.

Djaafar, T.F., S. Rahayu dan M. Gardjito. 2009. Pengaruh Blanching dan Waktu Perebusan dalam Larutan Kapur terhadap Kandungan Racun pada Umbi dan Criping Gadung. Jurnal Penelitian Tanaman Pangan, 28(3): 192-198.

Ferinda, M. 2017. Daya Racun Ekstrak Umbi Gadung (Discorea hispida Dennst) Terhadap Hama Keong Emas (Pomacea sp.) dan Ikan Lele (Clarias sp.) di Rumah Kaca. Skripsi (Tidak Dipublikasikan). Universitas Lampung, Bandar Lampung.

Gassa, A., A. Nasaruddin dan S. Thamrin. 2007. Pestisida dan Aplikasinya. Laboratorium Toksikologi dan Bahan Alami Jurusan Hama dan Penyakit Tumbuhan.Universitas Hasanuddin, Makassar.

Kardinan, A. 2011. Penggunaan Pestisida Nabati sebagai Kearifan Lokal dalam Pengendalian Hama Tanaman Menuju Sistem Pertanian Organik. Jurnal Pengembangan Inovasi Pertanian, 4(4): 262- 277.

Natawigena. 1993. Entomologi Pertanian. Orba Shakti. Bandung. Pengaruh Konsentrasi Ekstrak Bahan Pestisida Nabati terhadap Hama. Balai Penelitian Tanaman Obat, Bogor.

Purba, S. 2007. Uji Efektifitas Ekstrak Biji Mengkudu (Morinda citrifolia) terhadap Plutella xylostella (Lepidoptera: Plutelidae) di Laboratorium. Skripsi (Tidak Dipublikasikan). Fakultas Pertanian, Universitas Sumatra Utara, Medan.

Sari, M. 2013. Uji Efektifitas Beberapa Insektisida Nabati untuk Mengendalikan Ulat Grayak (Spodoptera litura F.) di laboratorium. Jurnal Online Agroteknologi, 1(3): 2337-6597.

Setiawan, A. N. dan S. Achmad 2014. Uji Efektifitas Berbagai Konsentrasi Pestisida Nabati Bintaro (Cerbera manghas) terhadap Hama Ulat Gerayak (Spodoptera litura) pada Tanaman Kedelai. Planta Tropica Journal of Agro Scence, 2(2): 99105.

Sukayat, D. 2010. Permasyarakatan Pestisida Nabati dalam Pengendalian OPT Pangan dan Hortikultura. Online pada: http://hortikultura-garut.com/, Diakses Tanggal 22 Agusutus 2019.

Sulfahri. 2006. Insektisida dari Umbi Gadung. Online pada: http://www.lipi. go.id/www.egi, Diakses Tanggal 17 Maret 2020.

Svasty, M. R. 1999. Characterization of a Novel Ratenoid $\beta$-glukosidase Enzyme and its Natural Substrat. Chulabhorn Research Institute, Bangkok.

Tarumingkeng. 2001. Serangga dan Lingkungan. Institut Pertanian Bogor, Bogor.

Tukimin dan M. Rizal, 2002. Pengaruh Ekstrak Daun Gamal (Gliricidia sepium) Terhadap Mortalitas Kutu Daun Kapas Aphis gossypii Glover. Balittas, Malang.

Wijayanti, R., L. Wibowo, dan Solikhin. 2016. Pengaruh Varietas Padi dan Jjenis Kelamin Keong Mas terhadap Daya Rusak Keong Mas pada Tanaman Padi. Jurnal Agrotek Tropika, 4(2): 141-145.

Wiratno, M. Rizal dan W. Laba. 2011. Potensi Ekstrak Tanaman Obat dan Aromatik sebagai Pengendali Keong Mas. Buletin Littro. 22(1): 54-64.

Yani, T. 2017. Uji Potensi Sari Pati Gadung (Dioscorea hispida) sebagai Boinsektisida Hama Walang Sangit (Leptocorisa acuta) Tanaman Padi (Oryza sativa). Skripsi (Tidak Dipublikasikan). Program Studi Pendidikan Biologi, Universitas Musi Rawas, Lubuk Linggau.

Yasa, M.R., N. Adijaya, A. A. N. B. Kamandalu, K. Mahaputra, P. A. Kertawirawan, P. Sugiarta, P. Anggoro, W. Sunanjaya, J. Rinaldi, 
N. L. G. Budiari dan M. Sugianyar.

2013. Potensi dan Permasalahan

Sepuluh Calon Lokasi Program Gerbang Pangan Serasi Tahun 2014.

Badan Perencanaan Daerah

Kabupaten Tabanan bekerja sama dengan Balai Pengkajian Teknologi Pertanian, Bali. 